This document was prepared in conjunction with work accomplished under Contract No. DE-AC09-96SR18500 with the U. S. Department of Energy.

\title{
DISCLAIMER
}

This report was prepared as an account of work sponsored by an agency of the United States Government. Neither the United States Government nor any agency thereof, nor any of their employees, nor any of their contractors, subcontractors or their employees, makes any warranty, express or implied, or assumes any legal liability or responsibility for the accuracy, completeness, or any third party's use or the results of such use of any information, apparatus, product, or process disclosed, or represents that its use would not infringe privately owned rights. Reference herein to any specific commercial product, process, or service by trade name, trademark, manufacturer, or otherwise, does not necessarily constitute or imply its endorsement, recommendation, or favoring by the United States Government or any agency thereof or its contractors or subcontractors. The views and opinions of authors expressed herein do not necessarily state or reflect those of the United States Government or any agency thereof. 


\section{Determination of Fissile Loadings onto Monosodium Titanate (MST) under Conditions Relevant to the Actinide Removal Process Facility}

by

THOMAS PETERS

Westinghouse Savannah River Company

Savannah River Site

Aiken, South Carolina 29808

Additional Authors:

DAVID HOBBS

SAMUEL FINK

This paper was prepared in connection with work done under the above contract number with the U. S. Department of Energy. By acceptance of this paper, the publisher and/or recipient acknowledges the U. S. Government's right to retain a nonexclusive, royalty-free license in and to any copyright covering this paper, along with the right to reproduce and to authorize others to reproduce all or part of the copyrighted paper. 
Key Words: High Level Waste

Actinide Removal Process

Strontium

Retention: Permanent

Determination of Fissile Loadings onto Monosodium Titanate (MST) under Conditions Relevant to the Actinide Removal Process Facility

\author{
T. B. Peters \\ D. T. Hobbs \\ S. D. Fink
}

November 15, 2005

Savannah River National Laboratory

Washington Savannah River Company

Savannah River Site

Aiken, SC 29808

Prepared for the U.S. Department of Energy Under

Contract Number DE-AC09-96SR18500

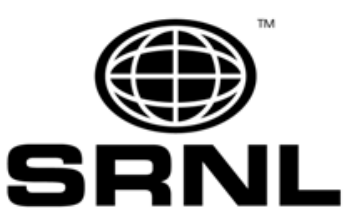




\section{DISCLAIMER}

This report was prepared for the United States Department of Energy under Contract No. DE-AC09-96SR18500 and is an account of work performed under that contract. Reference herein to any specific commercial product, or process, does not necessarily constitute or imply endorsement, recommendation, or favoring of same by Westinghouse Savannah River Company or by the United States Government or any agency thereof. The views and opinions of the authors expressed herein do not necessarily state or reflect those of the United States Government or any agency thereof.

Printed in the United States of America

Prepared For

U.S. Department of Energy 
WSRC-TR-2005-00514, REV. 0

\section{REVIEWS AND APPROVALS}

\section{AUTHORS}

Thomas B. Petes

$1-4-2006$

T. B. Peters, co-author

Date

Dait 1.65

$1 / 4 / 2006$

D. T. Hobbs, co-author

Date

DESIGN CHECK (per Manual E7, Procedure 2.40)

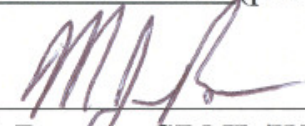

M. J. Barnes, SRNL/WPT

$1 / 4106$

Date

\section{APPROVALS}

Sanuel \&. Fink

S. D. Fink, Manager, Liquid Waste Processing Group

$1 / 4 / 2006$

S. D. Fink, Manager, Liquid Waste Processing Group

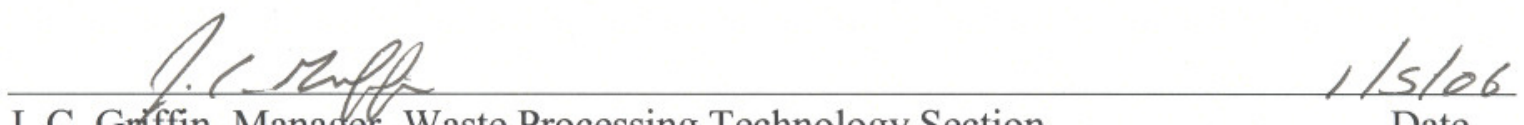

J. C. Gruffin, Manager, Waste Processing Technology Section

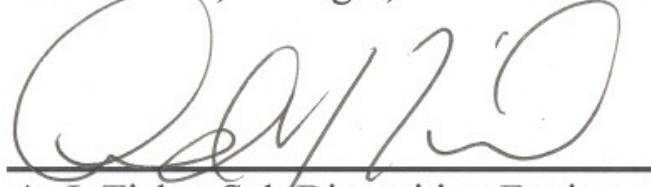

A. J. Tisler, Sal/Disposition Engineering

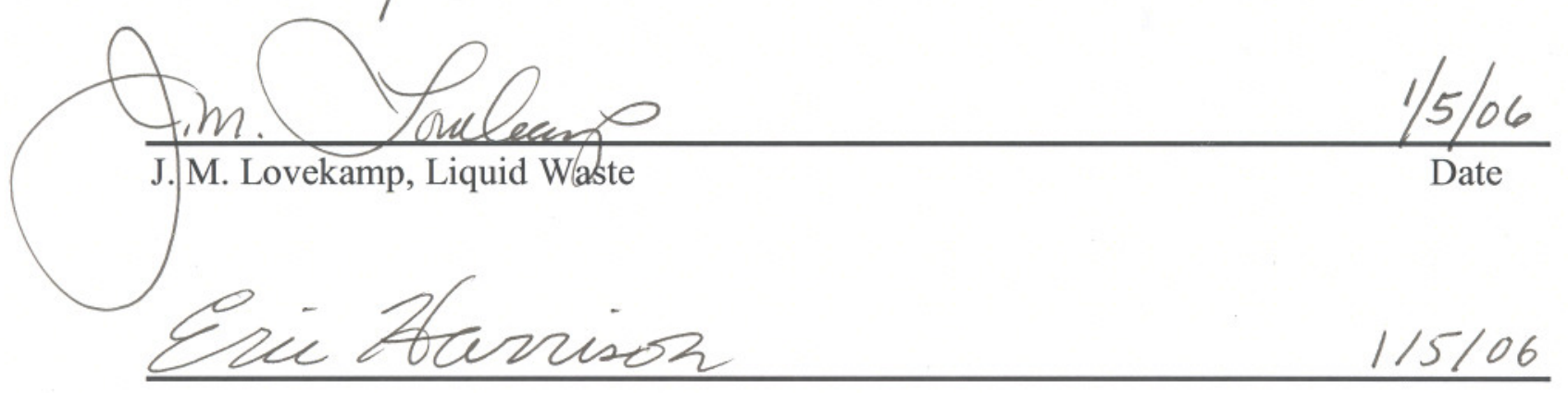

E. W. Harrison, Actinide Removal/Salt Characterization

Date 


\section{LIST OF ACRONYMS}

$\begin{array}{ll}\text { AA } & \text { Atomic Absorption } \\ \text { ADS } & \text { Analytical Development Section } \\ \text { ARP } & \text { Actinide Removal Process } \\ \text { CSSX } & \text { Caustic-Side Solvent Extraction } \\ \text { DDI } & \text { Distilled deionized water } \\ \text { DOE } & \text { Department of Energy } \\ \text { DWPF } & \text { Defense Waste Processing Facility } \\ \text { HLW } & \text { High Level Waste } \\ \text { ICP-ES } & \text { Inductively Coupled Plasma - Emissions } \\ & \text { Spectroscopy } \\ \text { ICP-MS } & \text { Inductively Coupled Plasma - Mass Spectroscopy } \\ \text { MST } & \text { Monosodium Titanate } \\ \text { PuTTA } & \text { Plutonium Thenoyl Trifluoroacetone } \\ \text { SRS } & \text { Savannah River Site } \\ \text { SRNL } & \text { Savannah River National Laboratory } \\ \text { SPF } & \text { Saltstone Production Facility } \\ \text { WPTS } & \text { Waste Processing Technology Section }\end{array}$




\subsection{EXECUTIVE SUMMARY}

This report describes the results of an experimental study to measure the sorption of fissile actinides on monosodium titanate (MST) at conditions relevant to operation of the Actinide Removal Process (ARP). The study examined the effect of a single contact of a large volume of radionuclide-spiked simulant solution with a small mass of MST. The volume of simulant to MST (8.5 L to $0.2 \mathrm{~g}$ of MST solids) was designed to mimic the maximum phase ratio that occurs between the multiple contacts of MST and waste solution and washing of the accumulated solids cycle of ARP. This work provides the following results.

- After a contact time of $\sim 2$ weeks, we measured the following actinide loadings on the MST (average of solution and solids data),

$$
\begin{aligned}
& \text { Pu: } 2.79 \pm 0.197 \mathrm{wt} \% \text {, } \\
& \text { U: } 14.0 \pm 1.04 \mathrm{wt} \% \text {, and } \\
& \text { Np: } 0.839 \pm 0.0178 \mathrm{wt} \% .
\end{aligned}
$$

- The plutonium and uranium loadings reported above are considerably higher than previously reported values. ${ }^{1,2,3}$ The higher loading result from the very high phase ratio and the high initial mass concentrations of uranium and plutonium. A separate upcoming document details the predicted values for this system versus the results.

- The strontium DF values measured in these tests proved much lower than those reported previously with simulants having the same bulk chemical composition. ${ }^{4}$ The low strontium DF values reflect the very low initial mass concentration of strontium in this simulant $(\leq 100 \mu \mathrm{g} / \mathrm{L})$ compared to that in previous testing $(\geq 600 \mu \mathrm{g} / \mathrm{L})$.

\subsection{INTRODUCTION}

The Actinide Removal Process (ARP) serves to remove radioactive strontium and alpha activity from high-level waste solutions. High level waste transfers into the batch reactor and contacts MST. After 24-hours of contact, the suspension is filtered to affect a separation of the solids and the decontaminated solution. The decontaminated waste solution transfers on to either the Modular Caustic-Side Solvent Extraction Unit or the Saltstone Disposal Facility. The MST solids remain in the batch reactor. This operation is repeated until there are sufficient solids for transfer into the Defense Waste Processing Facility (DWPF). Current operational planning indicates that as many as 17 batch contacts will occur in a process cycle. 
Testing in support of the down selection of technology for SRS waste pretreatment technology measured uranium loadings onto MST well above the maximum value determined under conditions relevant to the now-abandoned In-Tank Precipitation (ITP) process. ${ }^{2}$ The higher uranium loadings onto MST and the operational strategy of up to 17 batch contacts provides an opportunity for much higher fissile loadings onto the MST in the ARP facility compared to the ITP facility. Thus, CBU requested that SRNL determine fissile loadings of uranium, plutonium and neptunium under conditions relevant to the ARP facility. ${ }^{5,6}$ This report provides a summary of the results of this study.

\subsection{EXPERIMENTAL}

The tests used a simulated waste solution prepared specifically for this work. The bulk chemical composition of this simulant is identical to that developed by SRNL for testing MST performance in support of salt processing at the Savannah River Site. ${ }^{7,8,9}$ Table 1 provides the target chemical and radiochemical composition of the simulant. The quantities of actinide components derive from SRNL solubility calculations and were selected to maximize the loading of actinides onto the MST. The selected target actinide concentrations are considered reasonable approximations of the maximum soluble concentrations anticipated for ARP operations based on feed stream predictions.

A high concentration of strontium could potentially reduce the loading of the actinide elements onto the MST. Thus, we minimized the concentration of stable strontium in the simulant to reduce the potential for loading strontium onto the MST. We prepared the simulant using reagent grade chemicals and deionized distilled water (DDI) in accordance with the established procedure. ${ }^{10}$

To satisfy all the goals of this study, the researchers followed a series of steps detailed below.

- Technicians prepared the simulant solution. The simulant was verified to contain the proper quantities of ${ }^{85} \mathrm{Sr},{ }^{238} \mathrm{U}$, and ${ }^{239 / 240} \mathrm{Pu}$ according to SRNL procedures (see Appendix I).

- The prepared simulant stirred for 2 weeks to allow for the actinides to equilibrate into solution. During equilibrium the simulant was sampled for supernatant radioisotope concentrations. At the end of 2 weeks it appeared that equilibration was complete and the simulant was deemed ready for use (see Appendix I).

- Technicians split the simulant into three experimental bottles (Bottles \#1, \#2, \#3) and one control bottle. Each bottle contained $8.5 \mathrm{~L}$ of the simulant solution. 
- Personnel added $0.2 \mathrm{~g}$ of MST solids (0.0235 g MST/L) prepared by Optima Chemicals, Inc. (Batch \#00-QAB-417) to each bottle and allowed contact for 7 days. The bottles were agitated using a magnetic stirrer.

- During the 7 day period, technicians sampled the supernatant in the experiment and control bottles at 4, 6, 8, 24, 96, and 168 hours. Due to delays in filtering, a final filtrate sample was pulled just after filtration finished for each bottle. This final sample occurred at either 336 or 384 hours (depending on which bottle).

- At the completion of testing, the technicians filtered the MST using a removable $0.45 \mu \mathrm{m}$ nylon filter and retained the MST for analyses.

Table 1. Target Composition of Simulated Waste Solution

\begin{tabular}{|c|c|}
\hline Component & Target Concentration \\
\hline $\mathrm{NaNO}_{3}$ & $2.60 \mathrm{M}$ \\
\hline $\mathrm{NaOH}$ & $1.33 \mathrm{M}$ \\
\hline $\mathrm{Na}_{2} \mathrm{SO}_{4}$ & $0.521 \mathrm{M}$ \\
\hline $\mathrm{NaAl}(\mathrm{OH})_{4}$ & $0.429 \mathrm{M}$ \\
\hline $\mathrm{NaNO}_{2}$ & $0.134 \mathrm{M}$ \\
\hline $\mathrm{Na}_{2} \mathrm{CO}_{3}$ & $0.0260 \mathrm{M}$ \\
\hline $\mathrm{T}^{2} \mathrm{Nal} \mathrm{Na}^{+}$ & $5.60 \mathrm{M}$ \\
\hline $\mathrm{Cold}^{\mathrm{Strontium}}$ & $\sim 100 \mu \mathrm{g} / \mathrm{L}$ \\
\hline${ }^{85} \mathrm{Sr}$ & $9.54 \mathrm{E}-04 \mu \mathrm{g} / \mathrm{L}$ \\
\hline${ }^{237} \mathrm{~Np}$ & $500 \mu \mathrm{g} / \mathrm{L}$ \\
\hline${ }^{238} \mathrm{U}$ & $25,000 \mu \mathrm{g} / \mathrm{L}$ \\
\hline${ }^{239 / 40} \mathrm{Pu}$ & $1200 \mu \mathrm{g} / \mathrm{L}$ \\
\hline
\end{tabular}

The three bottles used in the experiments are replicates of each other. Control samples were pulled at the same time of the experimental samples, except for the 336 or 384 hour sample.

The experiments did not include the presence of any entrained sludge solids. The presence of solids would add the potential for leaching radionuclides from the sludge and could provide a variation in the concentrations of potential sorbates in solution.

\footnotetext{
$\checkmark$ SRNL did not deliberately add cold strontium. In such cases $\leq 100 \mu \mathrm{g} / \mathrm{L}$ of stable strontium typically enters the simulant as impurities from the chemical reagents, based on measurements of prior simulants prepared in this manner.
} 
All experiments were performed at ambient laboratory temperature and pressure. The temperature was monitored at least once per day and ranged from 18.8 to $21.8^{\circ} \mathrm{C}$ over the testing period.

\subsection{Sampling Methodology}

For each solution sample, we removed a sub-surface aliquot from the test bottle. We filtered through a $0.1 \mu \mathrm{m}$ syringe filter to remove any solids and acidified a measured volume of the filtrate with an equal volume of 5.0 $\mathrm{M} \mathrm{HNO}_{3}$. We inspected the acidified samples after standing for a minimum of 2 hours for evidence of solids. The presence of solids could introduce an error into the determination of fissile concentrations. All acidified samples were found to be clear with no evidence of any solids.

Table 2 lists the analyses for the solution and recovered MST solids samples. We corrected the reported ${ }^{85} \mathrm{Sr}$ gamma activities for decay between the time the sample was taken and the gamma spectrum was recorded.

At the conclusion of the experiment we recovered the MST solids by filtration. We attempted to dissolve the recovered solids in a 1:1 mixture of concentrated sulfuric acid and water. Previous testing found that MST solids loaded with plutonium and uranium readily dissolved in this acidic solution. ${ }^{3}$ We observed that the solids from Bottle \#3 readily dissolved in the sulfuric acid solution. However, the solids recovered from Bottles \#1 and \#2 did not completely dissolve.

Additions of $\mathrm{HNO}_{3}, \mathrm{H}_{2} \mathrm{O}_{2}$, and $\mathrm{NaF}$ also failed to completely dissolve these solids. Thus, we filtered dissolution suspensions and recovered the undissolved solids and the filtrate from this step. The filtrate was recovered, diluted to a known volume and submitted to determine titanium, actinide and ${ }^{85} \mathrm{Sr}$ content. We recovered the undissolved solids and performed a sodium peroxide fusion to convert the solids to a form that would dissolve in acid. The peroxide fusion proved successful and we determined the titanium, actinide and ${ }^{85} \mathrm{Sr}$ content of these solids as well.

Table 2. Sample Analysis Plans

\begin{tabular}{|c|c|c|}
\hline Analysis & $\begin{array}{c}\text { Simulated } \\
\text { Waste Solution }\end{array}$ & $\begin{array}{c}\text { Digested } \\
\text { MST Solids }\end{array}$ \\
\hline ICP-ES (Ti) & & $\mathbf{X}$ \\
\hline ICP-MS (U) & $\mathbf{X}$ & $\mathbf{X}$ \\
\hline Gamma scan $(\mathrm{Sr})$ & $\mathbf{X}$ & $\mathbf{X}$ \\
\hline PuTTA $(\mathrm{Pu})$ & $\mathbf{X}$ & $\mathbf{X}$ \\
\hline
\end{tabular}




\subsection{EXPERIMENTAL RESULTS}

The chemical and radiochemical composition of the simulant met the target concentrations for all components except plutonium. The plutonium concentration measured $885 \mu \mathrm{g} / \mathrm{L}$ compared to the target of $1200 \mu \mathrm{g} / \mathrm{L}$. This result is not unexpected as a value of $885 \mu \mathrm{g} / \mathrm{L}$ falls within the confidence interval for plutonium solubility for a solution having the chemical composition as listed in Table 1.

The plutonium concentration in this simulant is about a factor of 4 higher than that used in previous simulant testing ${ }^{7,8,9}$ and a factor of 2 higher than that in actual waste testing. ${ }^{11}$ At the conclusion of the experiment, the solution contained approximately $120 \mu \mathrm{g} / \mathrm{L}$ of plutonium. This indicates that the system contained sufficient total mass of plutonium for achieving high mass loadings onto the MST solids. Note that the solution concentration of plutonium was continuing to decrease with the final sampling time (ca. 2 weeks). This indicates that the system may not have reached equilibrium at the time we concluded the experiment.

At the end of the experiment, the loaded MST solids were recovered by filtration. MST solids recovery ranged from $33.4 \%$ to $78.1 \%$, as measured by titanium content upon dissolution of the recovered solids. Solids losses likely reflect retention of the small quantities of solids (44 - $130 \mathrm{mg}$ MST) within the large 10 liter carboys used for the tests.

Recovered solids from two of the tests contained a small amount of solids that did not dissolve in sulfuric acid even upon addition of additional oxidizing and complexing agents, hydrogen peroxide and fluoride, respectively. We believe that these solids were aluminosilicates formed from the aluminum in the simulant and silicates leached from the filtering glassware. We affected dissolution of these solids using a peroxide fusion technique developed by the Analytical Development Section of SRNL. Analysis of the solutions produced by this dissolution technique revealed that these residual solids showed negligible amounts of actinides or strontium.

\subsection{Plutonium Results}

\subsubsection{Plutonium Removal from Solution}

Table 3 provides the solution concentrations of plutonium at each sampling time for the test and control bottles by the PuTTA and ICP-MS methods. Table 4 provides the decontamination factors (DF) for each sampling time. Figures 3 and 4 are the graphical representations of the data. The results show a high degree of precision among the three replicates and the analytical methods.

Due to the large liquid:MST ratio, the rate of removal and final DF values are less than under lower phase ratio and lower initial sorbate concentrations. After approximately 
two weeks of contact, the average final DF measured 7.65. Caution should be exercised when using the short term ( $<24$ hours) data. The short contact time data is difficult to distinguish from the control when evaluated with the analytical uncertainty.

Table 3. Plutonium Activities and Concentrations

\begin{tabular}{|c|c|c|c|c|c|c|c|c|}
\hline \multirow{2}{*}{$\begin{array}{l}\text { Time } \\
\text { (hours) }\end{array}$} & \multicolumn{4}{|c|}{$\begin{array}{c}{ }^{239 / 240} \mathrm{Pu} \text { Values by PuTTA } \\
\mu \mathrm{g} / \mathrm{L}\end{array}$} & \multicolumn{4}{|c|}{$\begin{array}{c}{ }^{239 / 240} \mathrm{Pu} \text { Values by ICP-MS } \\
\mu \mathrm{g} / \mathrm{L}\end{array}$} \\
\hline & Bottle 1 & Bottle 2 & Bottle 3 & Control & Bottle 1 & Bottle 2 & Bottle 3 & Control \\
\hline $0 *$ & \multicolumn{4}{|c|}{$882( \pm 94.6)$} & \multicolumn{4}{|c|}{$885( \pm 177)$} \\
\hline 4 & $740( \pm 41.4)$ & $727( \pm 35.6)$ & $855( \pm 53.0)$ & $731( \pm 36.6)$ & $706( \pm 141)$ & $717( \pm 143)$ & $686 \pm( \pm 137)$ & $798( \pm 160)$ \\
\hline 6 & $684( \pm 39.7)$ & $692( \pm 40.1)$ & $665( \pm 35.2)$ & $789( \pm 41.8)$ & $701( \pm 140)$ & $685( \pm 137)$ & $675( \pm 135)$ & $788( \pm 158)$ \\
\hline 8 & $679( \pm 34.0)$ & $678( \pm 33.2)$ & $716( \pm 35.1)$ & $732( \pm 35.2)$ & $687( \pm 137)$ & $671( \pm 134)$ & $680( \pm 136)$ & $788( \pm 158)$ \\
\hline 24 & $597( \pm 28.1)$ & $637( \pm 29.3)$ & $628( \pm 31.4)$ & $852( \pm 41.8)$ & $646( \pm 129)$ & $637( \pm 127)$ & $637( \pm 127)$ & $802( \pm 160)$ \\
\hline 96 & $505( \pm 26.3)$ & $470( \pm 21.6)$ & $473( \pm 25.1)$ & $858( \pm 41.2)$ & $473( \pm 94.6)$ & $499( \pm 99.9)$ & $484( \pm 96.9)$ & $786( \pm 157)$ \\
\hline 168 & $315( \pm 15.8)$ & $351( \pm 18.9)$ & $328( \pm 19.3)$ & $856( \pm 49.7)$ & $330( \pm 65.9)$ & $349( \pm 69.7)$ & $313( \pm 62.6)$ & $792( \pm 158)$ \\
\hline 336 & $121( \pm 6.27)$ & NA & NA & NA & $129 * *( \pm 25.8)$ & NA & NA & NA \\
\hline 384 & NA & $113( \pm 5.75)$ & $80.1( \pm 3.69)$ & NA & NA & $137 * *( \pm 27.3)$ & $141 * *( \pm 28.1)$ & NA \\
\hline
\end{tabular}

NA $=$ sample not pulled

* Time 0 is before MST addition and is the average of four values

$* *$ The time $=338$ and 384 samples report and use only ${ }^{239} \mathrm{Pu}$ values

Table 4. Plutonium DF Values

\begin{tabular}{|c|c|c|c|c|c|c|}
\hline \multirow{2}{*}{$\begin{array}{l}\text { Time } \\
\text { (hours) }\end{array}$} & \multicolumn{3}{|c|}{$\begin{array}{c}{ }^{239 / 240} \mathrm{Pu} \text { DF Values by } \\
\text { PuTTA }\end{array}$} & \multicolumn{3}{|c|}{$\begin{array}{c}{ }^{239 / 240} \mathrm{Pu} \text { DF Values by } \\
\text { ICP-MS }\end{array}$} \\
\hline & $\begin{array}{c}\text { Bottle } \\
1 \\
\end{array}$ & $\begin{array}{c}\text { Bottle } \\
2 \\
\end{array}$ & $\begin{array}{c}\text { Bottle } \\
3 \\
\end{array}$ & $\begin{array}{c}\text { Bottle } \\
1 \\
\end{array}$ & $\begin{array}{c}\text { Bottle } \\
2 \\
\end{array}$ & $\begin{array}{c}\text { Bottle } \\
3\end{array}$ \\
\hline 4 & 1.19 & 1.21 & 1.03 & 1.26 & 1.24 & 1.30 \\
\hline 6 & 1.29 & 1.27 & 1.33 & 1.27 & 1.30 & 1.32 \\
\hline 8 & 1.30 & 1.30 & 1.23 & 1.29 & 1.33 & 1.31 \\
\hline 24 & 1.48 & 1.38 & 1.40 & 1.38 & 1.40 & 1.40 \\
\hline 96 & 1.74 & 1.88 & 1.86 & 1.88 & 1.78 & 1.84 \\
\hline 168 & 2.80 & 2.51 & 2.69 & 2.70 & 2.55 & 2.84 \\
\hline 336 & 7.31 & NA & NA & $6.89 *$ & NA & NA \\
\hline 384 & NA & 7.83 & 11.0 & NA & $6.52 *$ & $6.33 *$ \\
\hline
\end{tabular}

* The time $=338$ and 384 samples report and use only ${ }^{239} \mathrm{Pu}$ values 
Figure 3. Plutonium Concentration versus Time as Measured by PuTTA

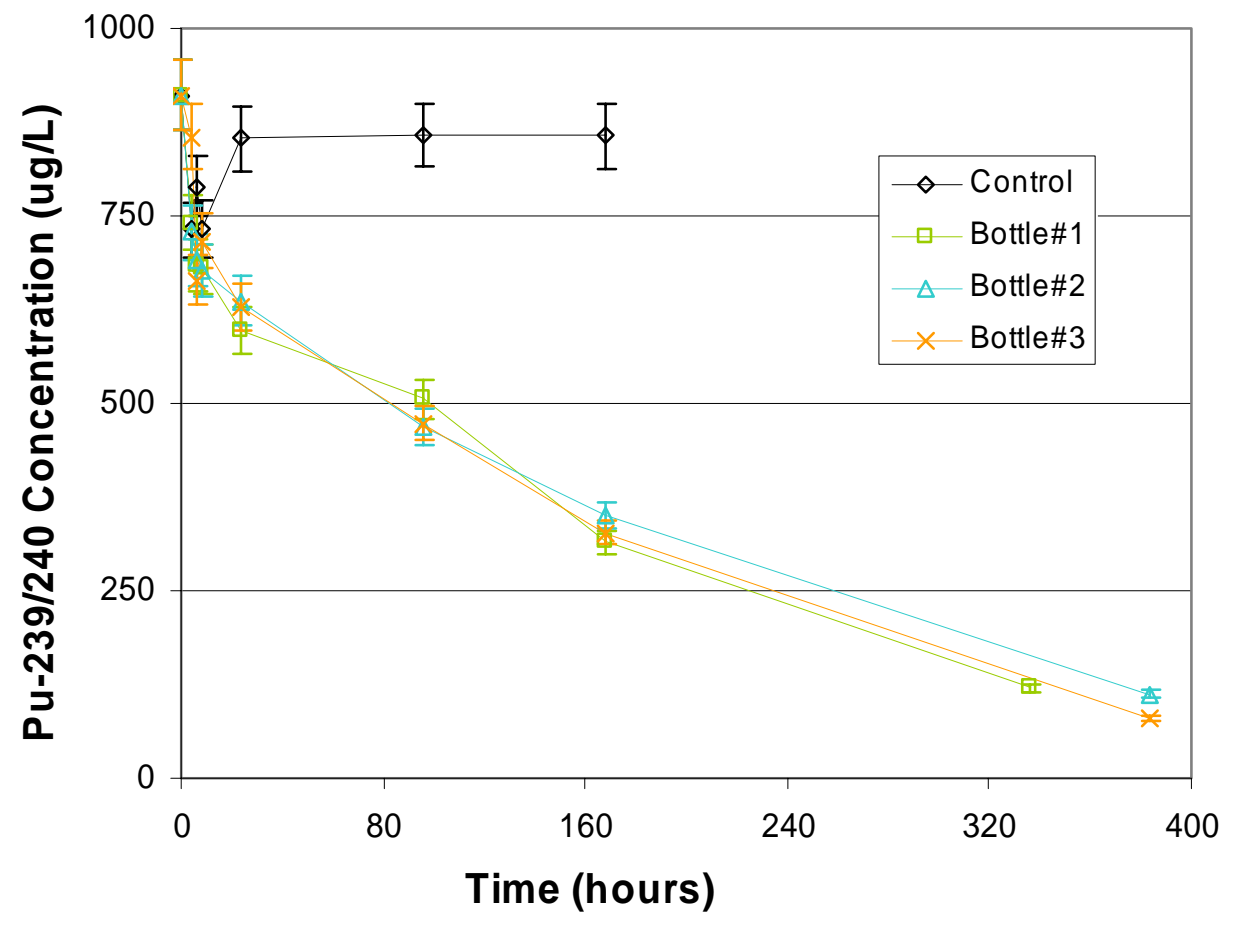

Figure 4. Plutonium Concentration versus Time as Measured by ICP-MS

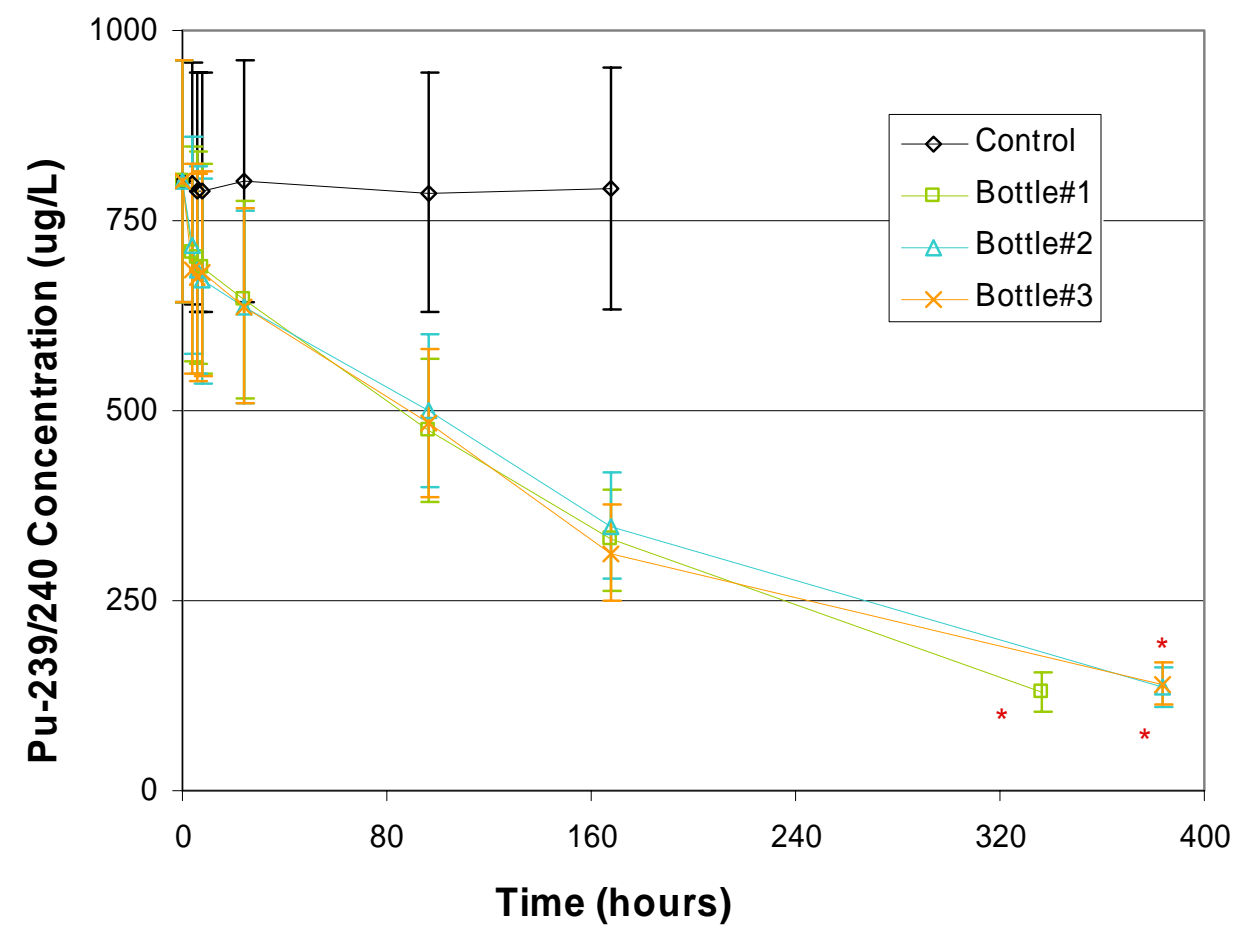


In Figure 4, the starred data points contain only ${ }^{239} \mathrm{Pu}$ data as the ${ }^{240} \mathrm{Pu}$ values fell below detection limits.

\subsubsection{Plutonium Loading onto MST}

Table 5 provides the measured loadings of plutonium onto MST for each test. Starred values at 336 or 384 hours of contact time are those measured from the recovered solids. All other values are those calculated based on the quantity of plutonium removed from solution and the quantity of MST added to each test bottle. Loading values are provided on weight percent (wt \%) and $\mu \mathrm{g} \mathrm{Pu} / \mathrm{g}$ MST bases. For the wt \% basis, the loading is calculated including the masses of all fissile elements (equation 1).

$$
W t \%=100 * \frac{g P u}{g P u+g U+g N p+g M S T}
$$

Table 5. ${ }^{239 / 240}$ Plutonium Loading on MST

\begin{tabular}{|c|c|c|c|c|c|c|}
\hline \multirow{2}{*}{$\begin{array}{c}\text { Sample } \\
\text { Time }\end{array}$} & \multicolumn{3}{|c|}{ Pu Loading (wt \%) } & \multicolumn{3}{c|}{ Pu Loading $(\mu \mathrm{g}$ Pu/g MST) } \\
\cline { 2 - 7 } & Bottle 1 & Bottle 2 & Bottle 3 & Bottle 1 & Bottle 2 & Bottle 3 \\
\hline PuTTA & & & & & & \\
\hline 4 & 0.558 & 0.608 & 0.104 & $6.02 \mathrm{E}+03$ & $6.56 \mathrm{E}+03$ & $1.14 \mathrm{E}+03$ \\
\hline 6 & 0.783 & 0.730 & 0.832 & $8.41 \mathrm{E}+03$ & $8.08 \mathrm{E}+03$ & $9.22 \mathrm{E}+03$ \\
\hline 8 & 0.797 & 0.783 & 0.642 & $8.62 \mathrm{E}+03$ & $8.68 \mathrm{E}+03$ & $7.05 \mathrm{E}+03$ \\
\hline 24 & 1.15 & 0.977 & 1.00 & $1.21 \mathrm{E}+04$ & $1.04 \mathrm{E}+04$ & $1.08 \mathrm{E}+04$ \\
\hline 96 & 1.46 & 1.59 & 1.55 & $1.60 \mathrm{E}+04$ & $1.75 \mathrm{E}+04$ & $1.74 \mathrm{E}+04$ \\
\hline 168 & 2.09 & 1.98 & 2.04 & $2.41 \mathrm{E}+04$ & $2.26 \mathrm{E}+04$ & $2.35 \mathrm{E}+04$ \\
\hline $336 / 384$ & 2.62 & 2.63 & 2.70 & $3.24 \mathrm{E}+04$ & $3.27 \mathrm{E}+04$ & $3.41 \mathrm{E}+04$ \\
\hline $336 / 384 *$ & 2.81 & 3.56 & 3.32 & $3.23 \mathrm{E}+04$ & $4.20 \mathrm{E}+04$ & $4.01 \mathrm{E}+04$ \\
\hline ICP-MS & & & & & & \\
\hline 4 & 0.721 & 0.679 & 0.788 & $7.80 \mathrm{E}+03$ & $7.33 \mathrm{E}+03$ & $8.66 \mathrm{E}+03$ \\
\hline 6 & 0.748 & 0.787 & 0.823 & $8.02 \mathrm{E}+03$ & $8.72 \mathrm{E}+03$ & $9.12 \mathrm{E}+03$ \\
\hline 8 & 0.796 & 0.838 & 0.810 & $8.61 \mathrm{E}+03$ & $9.30 \mathrm{E}+03$ & $8.91 \mathrm{E}+03$ \\
\hline 24 & 0.988 & 1.01 & 1.00 & $1.04 \mathrm{E}+04$ & $1.08 \mathrm{E}+04$ & $1.07 \mathrm{E}+04$ \\
\hline 96 & 1.61 & 1.51 & 1.54 & $1.77 \mathrm{E}+04$ & $1.66 \mathrm{E}+04$ & $1.72 \mathrm{E}+04$ \\
\hline 168 & 2.07 & 2.01 & 2.13 & $2.38 \mathrm{E}+04$ & $2.30 \mathrm{E}+04$ & $2.45 \mathrm{E}+04$ \\
\hline $336 / 384$ & 2.62 & 2.58 & 2.53 & $3.23 \mathrm{E}+04$ & $3.20 \mathrm{E}+04$ & $3.18 \mathrm{E}+04$ \\
\hline $336 / 384 *$ & 2.67 & 2.64 & 2.71 & $3.06 \mathrm{E}+04$ & $3.09 \mathrm{E}+04$ & $3.26 \mathrm{E}+04$ \\
\hline
\end{tabular}

* Starred data is derived from the loaded MST solids analyses whereas the rest of the data is derived from the filtrate data. 
From the filtrate data the average plutonium loadings measured

$0.576 \pm 0.245 \mathrm{wt} \%$ and $6.25 \pm 2.67 \mathrm{E}+03 \mu \mathrm{g} \mathrm{Pu} / \mathrm{g}$ MST after 4-hours of contact, $1.02 \pm 0.0647 \mathrm{wt} \%$ and $1.09 \pm 0.0633 \mathrm{E}+04 \mu \mathrm{g} \mathrm{Pu} / \mathrm{g}$ MST after 24-hours of contact, $2.05 \pm 0.0535 \mathrm{wt} \%$ and $2.36 \pm 0.071 \mathrm{E}+04 \mu \mathrm{g} \mathrm{Pu} / \mathrm{g}$ MST after 168-hours of contact, and

$2.62 \pm 0.0574 \mathrm{wt} \%$ and $3.26 \pm 0.0800 \mathrm{E}+04 \mu \mathrm{g} \mathrm{Pu} / \mathrm{g}$ MST after $\sim 360$-hours of contact. $^{\Pi}$

The analysis of the recovered MST solids after $\sim 360$ hours of contact ${ }^{\vee}$ provided an average plutonium loading of $2.95 \pm 0.390 \mathrm{wt} \%$ and $3.48 \pm 0.500 \mathrm{E}+04 \mu \mathrm{g}$ of $\mathrm{Pu}$ per $g$ of MST.

The closest previous data set is from previous work done in 1993. The previous data was collected at $19{ }^{\circ} \mathrm{C}$ after a 168 -hour contact time over a range of MST concentration ranging from $0.05-0.5 \mathrm{~g} / \mathrm{L}$ MST. From a loading curve derived from that work, the maximum plutonium loading at $0.0235 \mathrm{~g}$ MST per L of simulant (the conditions of this work) is estimated at $0.192 \mathrm{wt} \%$. The higher value reported in this testing is consistent with the much higher initial plutonium concentration in the simulant compared to the earlier testing.

\subsubsection{Plutonium Mass Balance}

One check of data consistency is whether the sum of the analytical results from the filtrate and solids match the known amounts of plutonium in solution before the addition of the MST. The plutonium in the final filtrate sample and the plutonium on the MST solids were compared to the plutonium in solution before the addition of MST (Table 6).

For the plutonium in the filtrate before MST addition, the value is the average of the four samples. For the plutonium on MST, the amount of plutonium captured on all the MST was corrected for the recovered quantity of MST. The \% Mass Balance term was derived by dividing the sum of the $\mathrm{Pu}$ in the filtrate and $\mathrm{Pu}$ on the MST by the $\mathrm{Pu}$ in the filtrate before MST addition.

The mass balance from the PuTTA analyses proved less precise than that based on the ICP-MS analyses. However, across all replicates and analyses the mass balance averaged $106 \pm 11.9 \%$, which indicates a very good mass balance for plutonium.

\footnotetext{
$\Pi$ The averaged data points contain both PuTTA and ICP-MS data.

$\checkmark$ The averages do not account for the slight differences in timing of the final samples for the three bottles. We consider the effect of the time difference to be minimal.
} 
Table 6. Plutonium Mass Balance

\begin{tabular}{|c|c|c|c|c|}
\hline & $\begin{array}{c}\text { Pu in Filtrate } \\
\text { Before MST } \\
(\mu \mathrm{g})\end{array}$ & $\begin{array}{c}\text { Pu in Filtrate } \\
\text { after MST } \\
(\mu \mathrm{g})\end{array}$ & $\begin{array}{c}\text { Pu on MST } \\
\text { Solids } \\
(\mu \mathrm{g})\end{array}$ & $\begin{array}{c}\text { \% Mass } \\
\text { Balance } \\
(\%)\end{array}$ \\
\hline PuTTA & & & & \\
\hline Bottle \#1 & $7497 \pm 804.0$ & 1030 & 6460 & 99.8 \\
\hline Bottle \#2 & $7497 \pm 804.0$ & 958 & 8410 & 125 \\
\hline Bottle \#3 & $7497 \pm 804.0$ & 681 & 8030 & 116 \\
\hline & & & & \\
\hline ICP-MS & & & & 95.5 \\
\hline Bottle \#1 & $7565 \pm 1513$ & 1100 & 6120 & 97.1 \\
\hline Bottle \#2 & $7565 \pm 1513$ & 1160 & 6180 & 102 \\
\hline Bottle \#3 & $7565 \pm 1513$ & 1200 & 6510 & \\
\hline
\end{tabular}

A second mass balance check can be calculated by comparing the $\sim 360$ hour filtrate against the solids data. A good mass balance will have both values close to each other. In this case, the filtrate data result of $3.26 \pm 0.0800 \mathrm{E}+04$ and the solids data result of $3.48 \pm 0.500 \mathrm{E}+04$ are within the combined uncertainties of each other.

\subsection{Uranium Results}

4.2.1 Uranium Removal from Solution

Table 7 provides the solution concentrations of uranium at each sampling time for the test and control bottles as determined by the ICP-MS method. Table 8 provides the decontamination factors (DF) for each sampling time. Figure 9 is the graphical representation of the data.

As with plutonium, the uranium results show a high degree of precision between all three replicates. Prior to 96-hours of contact, we cannot conclusively determine the degree of uranium removal. At or after 96-hours contact, the solution data indicates increasing uranium removal with increasing contact time. 
Table 7. Uranium Concentrations

\begin{tabular}{|c|c|c|c|c|}
\hline \multirow{2}{*}{$\begin{array}{c}\text { Time } \\
\text { (hours })\end{array}$} & \multicolumn{4}{|c|}{$235 / 238$ Uranium Values by ICPMS } \\
\cline { 2 - 5 } & Bottle 1 & \multicolumn{4}{|c|}{ Bottle 2} & Bottle 3 & Control \\
\hline $0 *$ & \multicolumn{4}{|c|}{$2.65 \mathrm{E}+04( \pm 5300)$} \\
\hline 4 & $2.49 \mathrm{E}+04( \pm 4980)$ & $2.49 \mathrm{E}+04( \pm 4980)$ & $2.45 \mathrm{E}+04( \pm 4900)$ & $2.49 \mathrm{E}+04( \pm 4980)$ \\
\hline 6 & $2.51 \mathrm{E}+04( \pm 5020)$ & $2.43 \mathrm{E}+04( \pm 4860)$ & $2.43 \mathrm{E}+04( \pm 4860)$ & $2.47 \mathrm{E}+04( \pm 4940)$ \\
\hline 8 & $2.49 \mathrm{E}+04( \pm 4980)$ & $2.43 \mathrm{E}+04( \pm 4860)$ & $2.45 \mathrm{E}+04( \pm 4900)$ & $2.47 \mathrm{E}+04( \pm 4940)$ \\
\hline 24 & $2.57 \mathrm{E}+04( \pm 5140)$ & $2.53 \mathrm{E}+04( \pm 5060)$ & $2.51 \mathrm{E}+04( \pm 5020)$ & $2.51 \mathrm{E}+04( \pm 5020)$ \\
\hline 96 & $2.47 \mathrm{E}+04( \pm 4940)$ & $2.47 \mathrm{E}+04( \pm 4940)$ & $2.43 \mathrm{E}+04( \pm 4860)$ & $2.49 \mathrm{E}+04( \pm 4980)$ \\
\hline 168 & $2.37 \mathrm{E}+04( \pm 4740)$ & $2.39 \mathrm{E}+04( \pm 4780)$ & $2.37 \mathrm{E}+04( \pm 4740)$ & $2.47 \mathrm{E}+04( \pm 4940)$ \\
\hline 336 & $2.21 \mathrm{E}+04( \pm 4410)$ & NA & NA & NA \\
\hline 384 & NA & $2.19 \mathrm{E}+04( \pm 4370)$ & $2.15 \mathrm{E}+0( \pm 4290)$ & NA \\
\hline
\end{tabular}

NA $=$ sample not pulled

* Time 0 is pre-MST and is the average of 4 pre-MST values

Table 8. Uranium DF Values

\begin{tabular}{|c|c|c|c|}
\hline \multirow{2}{*}{$\begin{array}{l}\text { Time } \\
\text { (hours) }\end{array}$} & \multicolumn{3}{|c|}{$\begin{array}{c}{ }^{235 / 238} \text { Uranium DF Values } \\
\text { by ICPMS }\end{array}$} \\
\hline & $\begin{array}{c}\text { Bottle } \\
1\end{array}$ & $\begin{array}{c}\text { Bottle } \\
2\end{array}$ & $\begin{array}{c}\text { Bottle } \\
3\end{array}$ \\
\hline 4 & 1.07 & 1.07 & 1.08 \\
\hline 6 & 1.06 & 1.09 & 1.09 \\
\hline 8 & 1.07 & 1.09 & 1.08 \\
\hline 24 & 1.03 & 1.05 & 1.06 \\
\hline 96 & 1.08 & 1.08 & 1.09 \\
\hline 168 & 1.12 & 1.11 & 1.12 \\
\hline 336 & 1.20 & NA & NA \\
\hline 384 & NA & 1.21 & 1.24 \\
\hline
\end{tabular}


WSRC-TR-2005-00514, REV. 0

Figure 5. Uranium Concentration Versus Time as Measured by ICP-MS

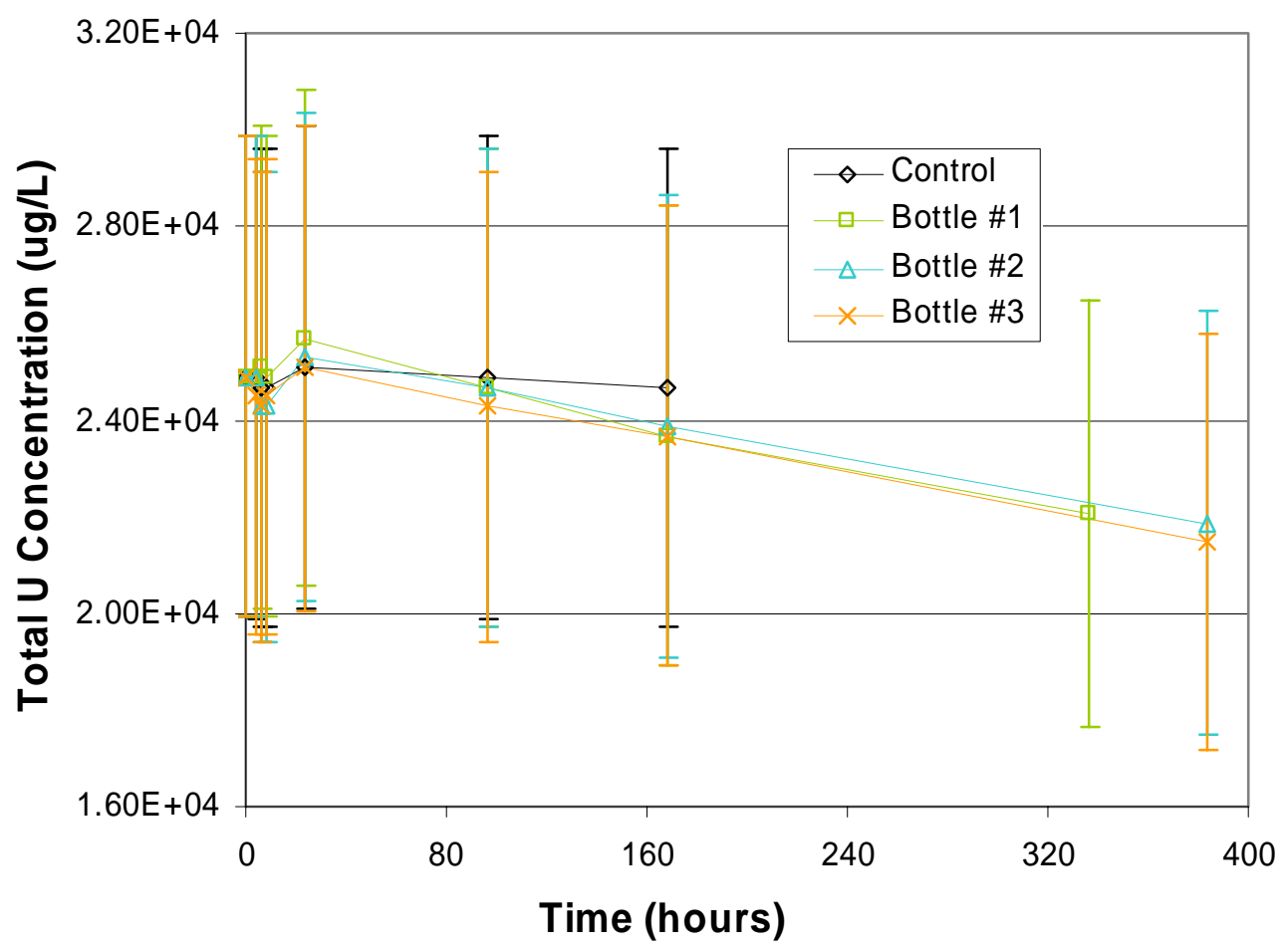

\subsubsection{Uranium Loading onto MST}

Table 9 provides the measured loadings of plutonium onto MST for each test. Starred values at 336 or 384 hours of contact time are those measured from the recovered solids. All other values are those calculated based on the quantity of uranium removed from solution and the quantity of MST added to each test bottle. Loading values are provided on weight percent (wt \%) and $\mu \mathrm{g} \mathrm{U/g}$ MST bases. For the wt \% basis, the loading is calculated using equation 1 except with the mass of uranium in the numerator.

Table 9. Uranium Loading on MST

\begin{tabular}{|c|c|c|c|c|c|c|}
\hline \multirow{2}{*}{ Analysis } & \multicolumn{3}{|c|}{ U Loading $(w t$ \%) } & \multicolumn{3}{c|}{ U Loading $(\mu \mathrm{g}$ U/g MST) } \\
\cline { 2 - 7 } & Bottle 1 & Bottle 2 & Bottle 3 & Bottle 1 & Bottle 2 & Bottle 3 \\
\hline 4 & 6.50 & 6.50 & 7.95 & $7.03 \mathrm{E}+04$ & $7.02 \mathrm{E}+04$ & $8.74 \mathrm{E}+04$ \\
\hline 6 & 5.76 & 8.65 & 8.65 & $6.18 \mathrm{E}+04$ & $9.59 \mathrm{E}+04$ & $9.59 \mathrm{E}+04$ \\
\hline 8 & 6.50 & 8.65 & 7.95 & $7.03 \mathrm{E}+04$ & $9.59 \mathrm{E}+04$ & $8.74 \mathrm{E}+04$ \\
\hline 24 & 3.46 & 5.00 & 5.77 & $3.63 \mathrm{E}+04$ & $5.33 \mathrm{E}+04$ & $6.20 \mathrm{E}+04$ \\
\hline 96 & 7.17 & 7.19 & 8.59 & $7.89 \mathrm{E}+04$ & $7.90 \mathrm{E}+04$ & $9.59 \mathrm{E}+04$ \\
\hline 168 & 10.6 & 9.90 & 10.6 & $1.22 \mathrm{E}+05$ & $1.13 \mathrm{E}+05$ & $1.22 \mathrm{E}+05$ \\
\hline $336 / 384$ & 15.4 & 16.0 & 17.1 & $1.90 \mathrm{E}+05$ & $1.98 \mathrm{E}+05$ & $2.15 \mathrm{E}+05$ \\
\hline $336 / 384^{*}$ & 9.39 & 11.0 & 13.2 & $1.08 \mathrm{E}+05$ & $1.29 \mathrm{E}+05$ & $1.58 \mathrm{E}+05$ \\
\hline
\end{tabular}

* Starred data is derived from the loaded MST solids analyses whereas the rest of the data is derived from the filtrate data. 
From the filtrate data the average uranium loadings measured

$6.98 \pm 0.837 \mathrm{wt} \%$ and $7.60 \pm 0.991 \mathrm{E}+04 \mu \mathrm{g} \mathrm{U} / \mathrm{g}$ MST after 4-hours of contact, $4.74 \pm 1.17 \mathrm{wt} \%$ and $5.06 \pm 1.31 \mathrm{E}+04 \mu \mathrm{g} \mathrm{U} / \mathrm{g}$ MST after 24-hours of contact, $10.3 \pm 0.379 \mathrm{wt} \%$ and $1.19 \pm 0.0495 \mathrm{E}+05 \mu \mathrm{g} \mathrm{U} / \mathrm{g}$ MST after 168-hours of contact, and

$16.7 \pm 0.870 \mathrm{wt} \%$ and $2.01 \pm 0.130 \mathrm{E}+05 \mu \mathrm{g} \mathrm{U} / \mathrm{g}$ MST after $\sim 360$-hours of contact. ${ }^{\nabla}$

The analysis of the MST solids recovered after approximately 2 weeks of contact provided an average uranium loading of $11.2 \pm 1.89 \mathrm{wt} \%$ and $1.32 \pm 0.252 \mathrm{E}+05 \mu \mathrm{g}$ $\mathrm{U} / \mathrm{g} \mathrm{MST}$.

The closest previous data set is from previous work done in 2002. The previous data was collected at $19{ }^{\circ} \mathrm{C}, 1$ week, at $0.2 \mathrm{~g} \mathrm{MST}$ per L of simulant. From that work, the maximum estimated $U$ loading was $5.13 \pm 0.509 \%$. The higher value reported in this testing is consistent with the higher initial uranium concentration in the simulant compared to the earlier testing.

\subsubsection{Uranium Mass Balance}

We used the same methodology described for plutonium to check the uranium mass balance. Table 10 provides the calculated values and mass balances for each test. The average mass balance across all replicates and analyses is $93.8 \pm 1.10 \%$, which indicates a very good mass balance for uranium.

Table 10. Uranium Mass Balance

\begin{tabular}{|l|c|c|c|c|}
\hline & $\begin{array}{c}\text { U in Filtrate } \\
\text { Before MST } \\
(\mu \mathrm{g})\end{array}$ & $\begin{array}{c}\text { U in Filtrate } \\
\text { after MST } \\
(\mu \mathrm{g})\end{array}$ & $\begin{array}{c}\text { U on MST } \\
\text { Solids } \\
(\mu \mathrm{g})\end{array}$ & $\begin{array}{c}\% \text { Mass } \\
\text { Balance } \\
(\%)\end{array}$ \\
\hline Bottle \#1 & $2.26 \pm 0.452 \mathrm{E}+05$ & $1.88 \mathrm{E}+05$ & $2.16 \mathrm{E}+04$ & 92.7 \\
\hline Bottle \#2 & $2.26 \pm 0.452 \mathrm{E}+05$ & $1.86 \mathrm{E}+05$ & $2.58 \mathrm{E}+04$ & 93.8 \\
\hline Bottle \#3 & $2.26 \pm 0.452 \mathrm{E}+05$ & $1.82 \mathrm{E}+05$ & $3.16 \mathrm{E}+04$ & 94.9 \\
\hline
\end{tabular}

A second mass balance check can be calculated by comparing the $\sim 360$ hour filtrate against the solids data. A good mass balance will have both values close to each other. In this case, the filtrate data result of $2.01 \pm 0.130 \mathrm{E}+05$ and the solids data result of $1.32 \pm 0.252 \mathrm{E}+05$ are $\sim 52 \%$ different. While the mass balance from both sets of data is quite good, when comparing against each other there is a large variance.

\footnotetext{
$\nabla$ The averages do not account for the slight differences in timing of the final samples for the three bottles. We consider the effect of the time difference to be minimal.
} 


\subsection{Neptunium Results}

\subsubsection{Neptunium Removal From Solution}

Table 11 provides the solution concentrations of neptunium at each sampling time for the test and control bottles as determined by the ICP-MS method. Table 12 provides the decontamination factors (DF) for each sampling time. Figure 13 is the graphical representation of the data.

As with plutonium and uranium, the neptunium results show a high degree of precision between all three replicates. Prior to 96-hours of contact, we cannot conclusively determine the degree of neptunium removal. At or after 96 -hours contact, the solution data indicates increasing neptunium removal with increasing contact time.

Table 11. ${ }^{237}$ Neptunium Concentration Over Time

\begin{tabular}{|c|c|c|c|c|}
\hline \multirow{2}{*}{$\begin{array}{c}\text { Time } \\
\text { (hours) }\end{array}$} & \multicolumn{4}{|c|}{${ }^{237}$ Neptunium Values by ICPMS } \\
\cline { 2 - 5 } & Bottle 1 & Bottle 2 & Bottle 3 & Control \\
\hline $0^{*}$ & \multicolumn{4}{|c|}{$477( \pm 95.3)$} \\
\hline 4 & $400( \pm 80.0)$ & $412( \pm 82.4)$ & $396( \pm 79.2)$ & $426( \pm 85.2)$ \\
\hline 6 & $406( \pm 81.2)$ & $392( \pm 78.4)$ & $400( \pm 80.0)$ & $418( \pm 83.6)$ \\
\hline 8 & $404( \pm 80.8)$ & $390( \pm 78.0)$ & $390( \pm 78.0)$ & $420( \pm 84.0)$ \\
\hline 24 & $422( \pm 84.4)$ & $416( \pm 83.2)$ & $418( \pm 83.6)$ & $434( \pm 86.8)$ \\
\hline 96 & $376( \pm 75.2)$ & $378( \pm 75.6)$ & $378( \pm 75.6)$ & $432( \pm 86.4)$ \\
\hline 168 & $328( \pm 65.6)$ & $340( \pm 68.0)$ & $328( \pm 65.6)$ & $426( \pm 85.2)$ \\
\hline 336 & $222( \pm 44.4)$ & NA & NA & NA \\
\hline 384 & NA & $228( \pm 45.6)$ & $216( \pm 43.2)$ & NA \\
\hline
\end{tabular}

$\mathrm{NA}=$ sample not pulled

* Time 0 is pre-MST and is the average of 4 pre-MST values 
Table 12. Neptunium DF Values

\begin{tabular}{|c|c|c|c|}
\hline \multirow{2}{*}{$\begin{array}{c}\text { Time } \\
\text { (hours) }\end{array}$} & \multicolumn{3}{|c|}{${ }^{237}$ Neptunium DF Values } \\
& Bottle & Bottle & Bottle \\
& 1 & 2 & 3 \\
\hline 4 & 1.19 & 1.16 & 1.20 \\
\hline 6 & 1.17 & 1.22 & 1.19 \\
\hline 8 & 1.18 & 1.22 & 1.22 \\
\hline 24 & 1.13 & 1.15 & 1.14 \\
\hline 96 & 1.27 & 1.26 & 1.26 \\
\hline 168 & 1.45 & 1.40 & 1.45 \\
\hline 336 & 2.15 & NA & NA \\
\hline 384 & NA & 2.09 & 2.21 \\
\hline \multicolumn{4}{|c}{ NA = sample not pulled } \\
\hline \multicolumn{3}{|c}{}
\end{tabular}

Figure 6. Neptunium Concentration Versus Time as Measured by ICP-MS

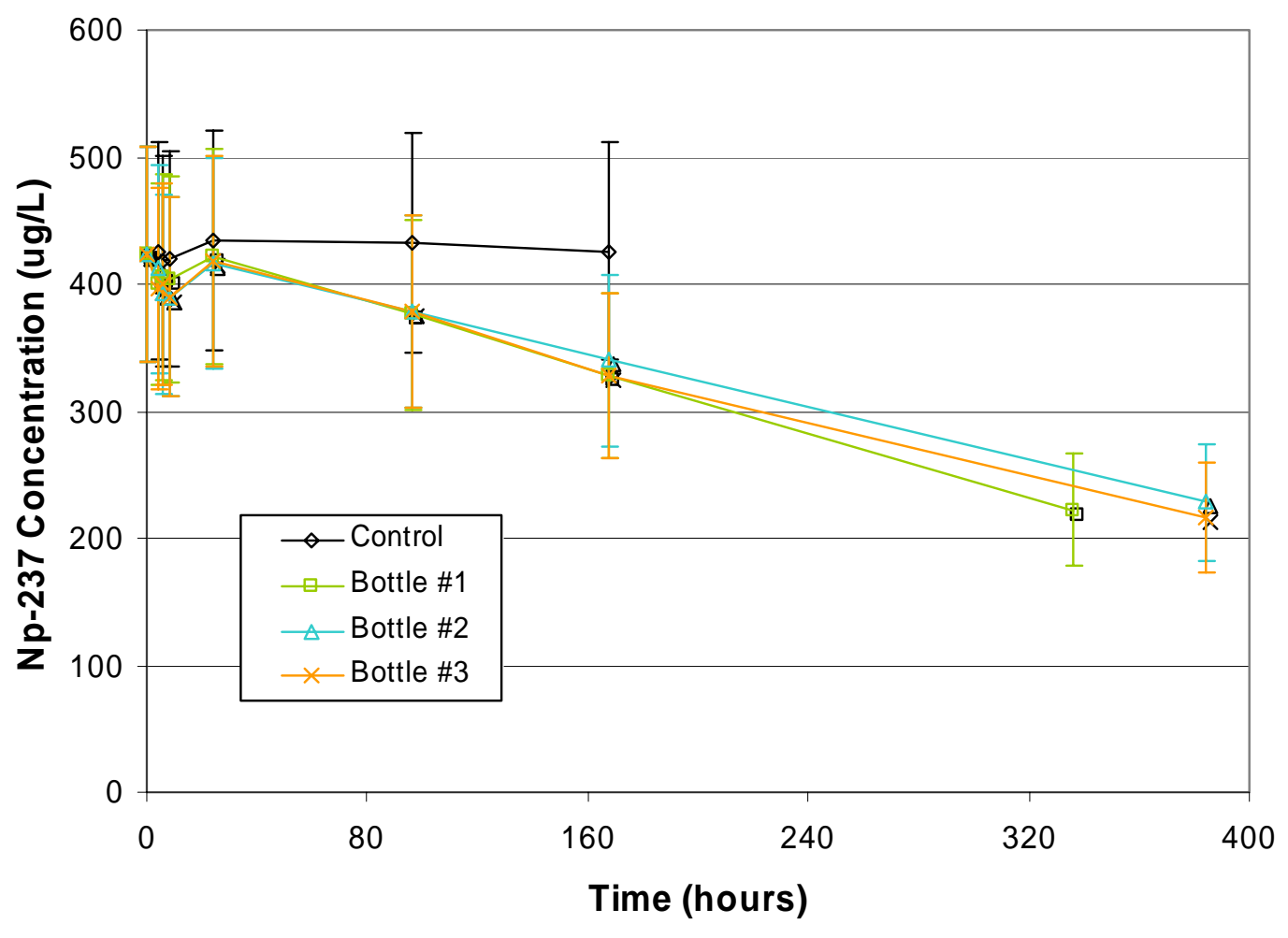




\subsubsection{Neptunium Loading on MST}

Table 13 provides the measured loadings of neptunium onto MST for each test. Starred values at 336 or 384 hours of contact time are those measured from the recovered solids. All other values are those calculated based on the quantity of neptunium removed from solution and the quantity of MST added to each test bottle. Loading values are provided on weight percent (wt \%) and $\mu \mathrm{g} \mathrm{Np/g} \mathrm{MST} \mathrm{bases.} \mathrm{For} \mathrm{the} \mathrm{wt} \mathrm{\%} \mathrm{basis,} \mathrm{the} \mathrm{loading} \mathrm{is}$ calculated using equation 1 except with the mass of neptunium in the numerator.

Table 13. ${ }^{237} \mathrm{~Np}$ Loading on MST

\begin{tabular}{|c|c|c|c|c|c|c|}
\hline \multirow{2}{*}{ Analysis } & \multicolumn{3}{|c|}{ Np Loading (wt \%) } & \multicolumn{3}{c|}{ Np Loading $(\mu \mathrm{g}$ Np/g MST) } \\
\cline { 2 - 7 } & Bottle 1 & Bottle 2 & Bottle 3 & Bottle 1 & Bottle 2 & Bottle 3 \\
\hline 4 & 0.301 & 0.254 & 0.311 & $3.25 \mathrm{E}+03$ & $2.74 \mathrm{E}+03$ & $3.42 \mathrm{E}+03$ \\
\hline 6 & 0.279 & 0.324 & 0.293 & $3.00 \mathrm{E}+03$ & $3.59 \mathrm{E}+03$ & $3.25 \mathrm{E}+03$ \\
\hline 8 & 0.285 & 0.332 & 0.334 & $3.08 \mathrm{E}+03$ & $3.68 \mathrm{E}+03$ & $3.68 \mathrm{E}+03$ \\
\hline 24 & 0.221 & 0.241 & 0.231 & $2.32 \mathrm{E}+03$ & $2.57 \mathrm{E}+03$ & $2.49 \mathrm{E}+03$ \\
\hline 96 & 0.388 & 0.381 & 0.375 & $4.27 \mathrm{E}+03$ & $4.19 \mathrm{E}+03$ & $4.19 \mathrm{E}+03$ \\
\hline 168 & 0.548 & 0.508 & 0.548 & $6.31 \mathrm{E}+03$ & $5.80 \mathrm{E}+03$ & $6.31 \mathrm{E}+03$ \\
\hline $336 / 384$ & 0.877 & 0.851 & 0.880 & $1.08 \mathrm{E}+04$ & $1.06 \mathrm{E}+04$ & $1.11 \mathrm{E}+04$ \\
\hline $336 / 384 *$ & 0.823 & 0.773 & 0.830 & $9.46 \mathrm{E}+03$ & $9.12 \mathrm{E}+03$ & $1.01 \mathrm{E}+04$ \\
\hline
\end{tabular}

* Starred data is derived from the loaded MST solids analyses whereas the rest of the data is derived from the filtrate data.

From the filtrate data the average uranium loadings measured

$0.289 \pm 0.0306 \mathrm{wt} \%$ and $314 \pm 0.354 \mathrm{E}+03 \mu \mathrm{g} \mathrm{Np} / \mathrm{g}$ MST after 4-hours of contact, $0.231 \pm 0.0101 \mathrm{wt} \%$ and $2.46 \pm 0.130 \mathrm{E}+03 \mu \mathrm{g} \mathrm{Np} / \mathrm{g}$ MST after 24-hours of contact, $0.535 \pm 0.0230 \mathrm{wt} \%$ and $6.14 \pm 0.294 \mathrm{E}+03 \mu \mathrm{g} \mathrm{Np} / \mathrm{g}$ MST after 168-hours of contact, and

$0.869 \pm 0.0159$ wt $\%$ and $1.08 \pm 0.0255 \mathrm{E}+04 \mu \mathrm{g}$ Np/g MST after $\sim 360$-hours of contact. ${ }^{\partial}$

The analysis of the MST solids recovered after approximately 2 weeks of contact provided an average loading of $0.809 \pm 0.0318 \mathrm{wt} \%$ and $9.55 \pm 0.472 \mathrm{E}+03 \mu \mathrm{g} \mathrm{Np} / \mathrm{g}$ of MST).

\subsubsection{Neptunium Mass Balance}

We used the same methodology described for plutonium to check the neptunium mass balance. Table 14 provides the calculated values and mass balances for each test. The average mass balance across all replicates and analyses is $93.8 \pm 1.07 \%$, which indicates a very good mass balance for neptunium.

\footnotetext{
${ }^{\partial}$ The averages do not account for the slight differences in timing of the final samples for the three bottles. We consider the effect of the time difference to be minimal.
} 
Table 14. Neptunium Mass Balance

\begin{tabular}{|l|c|c|c|c|}
\hline & $\begin{array}{c}\text { Np in Filtrate } \\
\text { Before MST } \\
(\mu \mathrm{g})\end{array}$ & $\begin{array}{c}\text { Np in Filtrate } \\
\text { after MST } \\
(\mu \mathrm{g})\end{array}$ & $\begin{array}{c}\text { Np on MST } \\
\text { Solids } \\
(\mu \mathrm{g})\end{array}$ & $\begin{array}{c}\text { \% Mass } \\
\text { Balance } \\
(\%)\end{array}$ \\
\hline Bottle \#1 & $4.05 \pm 0.810 \mathrm{E}+03$ & $1.89 \mathrm{E}+03$ & $1.89 \mathrm{E}+03$ & 93.3 \\
\hline Bottle \#2 & $4.05 \pm 0.810 \mathrm{E}+03$ & $1.94 \mathrm{E}+03$ & $1.82 \mathrm{E}+03$ & 93.0 \\
\hline Bottle \#3 & $4.05 \pm 0.810 \mathrm{E}+03$ & $1.84 \mathrm{E}+03$ & $2.01 \mathrm{E}+03$ & 95.0 \\
\hline
\end{tabular}

A second mass balance check can be calculated by comparing the $\sim 360$ hour filtrate against the solids data. A good mass balance will have both values close to each other. In this case, the filtrate data result of $1.08 \pm 0.0255 \mathrm{E}+04$ and the solids data result of $9.55 \pm 0.472 \mathrm{E}+03$ are only slightly outside of each others uncertainties.

\subsection{Strontium Results}

\subsubsection{Strontium Removal from Solution}

Table 15 provides the solution activities of ${ }^{85} \mathrm{Sr}$ at each sampling time for the test and control bottles as determined by gamma spectroscopy. Table 16 provides the decontamination factors (DF) for each sampling time. Figure 7 is the graphical representation of the data.

As with the actinide measurements, the ${ }^{85} \mathrm{Sr}$ results show a high degree of precision between all three replicates. Unlike the actinide measurements, we observed a rapid decrease in ${ }^{85} \mathrm{Sr}$ activity during the first 24 hours followed by a gradual decrease over the remaining time. The removal of ${ }^{85} \mathrm{Sr}$ proved very low (average DF of 2.65 after 2 week contact) compared to a strontium DF of 181 using a simulant containing much higher initial strontium concentration and contacted with $0.4 \mathrm{~g} / \mathrm{L}$ of MST for 1 week. The low decontamination factor is not unexpected given the high phase ratio of solution to MST solids and the low initial strontium concentration in the simulant. 


\section{Table 15. ${ }^{85}$ Strontium Activity versus Time as Measured by Gamma Spectroscopy}

\begin{tabular}{|c|c|c|c|c|}
\hline \multirow{2}{*}{$\begin{array}{c}\text { Time } \\
\text { (hours })\end{array}$} & \multicolumn{4}{|c|}{$\begin{array}{c}{ }^{85} \text { Sr Activity } \\
\mathrm{dpm} / \mathrm{mL}\end{array}$} \\
\cline { 2 - 5 } & Bottle 1 & \multicolumn{4}{|c|}{ Bottle 2} & Bottle 3 & Control \\
\hline $0 *$ & \multicolumn{3}{|c|}{$3.04 \mathrm{E}+04( \pm 592)$} \\
\hline 4 & $1.63 \mathrm{E}+04( \pm 455)$ & $1.60 \mathrm{E}+04( \pm 454)$ & $1.71 \mathrm{E}+04( \pm 473)$ & $2.93 \mathrm{E}+04( \pm 701)$ \\
\hline 6 & $1.64 \mathrm{E}+04( \pm 459)$ & $1.60 \mathrm{E}+04( \pm 452)$ & $1.50 \mathrm{E}+04( \pm 431)$ & $2.79 \mathrm{E}+04( \pm 677)$ \\
\hline 8 & $1.58 \mathrm{E}+04( \pm 445)$ & $1.53 \mathrm{E}+04( \pm 436)$ & $1.56 \mathrm{E}+04( \pm 44.3)$ & $2.80 \mathrm{E}+04( \pm 678)$ \\
\hline 24 & $1.49 \mathrm{E}+04( \pm 381)$ & $1.41 \mathrm{E}+04( \pm 393)$ & $1.50 \mathrm{E}+04( \pm 383)$ & $2.88 \mathrm{E}+04( \pm 647)$ \\
\hline 96 & $1.36 \mathrm{E}+04( \pm 396)$ & $1.35 \mathrm{E}+04( \pm 385)$ & $1.36 \mathrm{E}+04( \pm 357)$ & $2.81 \mathrm{E}+04( \pm 624)$ \\
\hline 168 & $1.25 \mathrm{E}+04( \pm 380)$ & $1.26 \mathrm{E}+04( \pm 384)$ & $1.32 \mathrm{E}+04( \pm 396)$ & $2.92 \mathrm{E}+04( \pm 700)$ \\
\hline 336 & $1.14 \mathrm{E}+04( \pm 263)$ & NA & NA & NA \\
\hline 384 & NA & $1.14 \mathrm{E}+04( \pm 262)$ & $1.16 \mathrm{E}+04( \pm 265)$ & NA \\
\hline
\end{tabular}

$$
\mathrm{NA}=\text { sample not pulled }
$$

* Time 0 is pre-MST and is the average of four values

Table 16. Strontium DF Values

\begin{tabular}{|c|c|c|c|}
\hline \multirow{2}{*}{$\begin{array}{c}\text { Time } \\
\text { (hours) }\end{array}$} & \multicolumn{3}{|c|}{ Sr DF Values } \\
\cline { 2 - 4 } & Bottle & Bottle & Bottle \\
2 & 3 \\
\hline 4 & 1.87 & 1.90 & 1.77 \\
\hline 6 & 1.85 & 1.90 & 2.02 \\
\hline 8 & 1.93 & 1.99 & 1.95 \\
\hline 24 & 2.04 & 2.15 & 2.02 \\
\hline 96 & 2.23 & 2.26 & 2.23 \\
\hline 168 & 2.43 & 2.40 & 2.29 \\
\hline 336 & 2.66 & NA & NA \\
\hline 384 & NA & 2.67 & 2.62 \\
\hline \multicolumn{3}{|c}{ NA } \\
\hline
\end{tabular}


WSRC-TR-2005-00514, REV. 0

Figure 7. ${ }^{85}$ Strontium Activity over Time by Gamma Spectroscopy

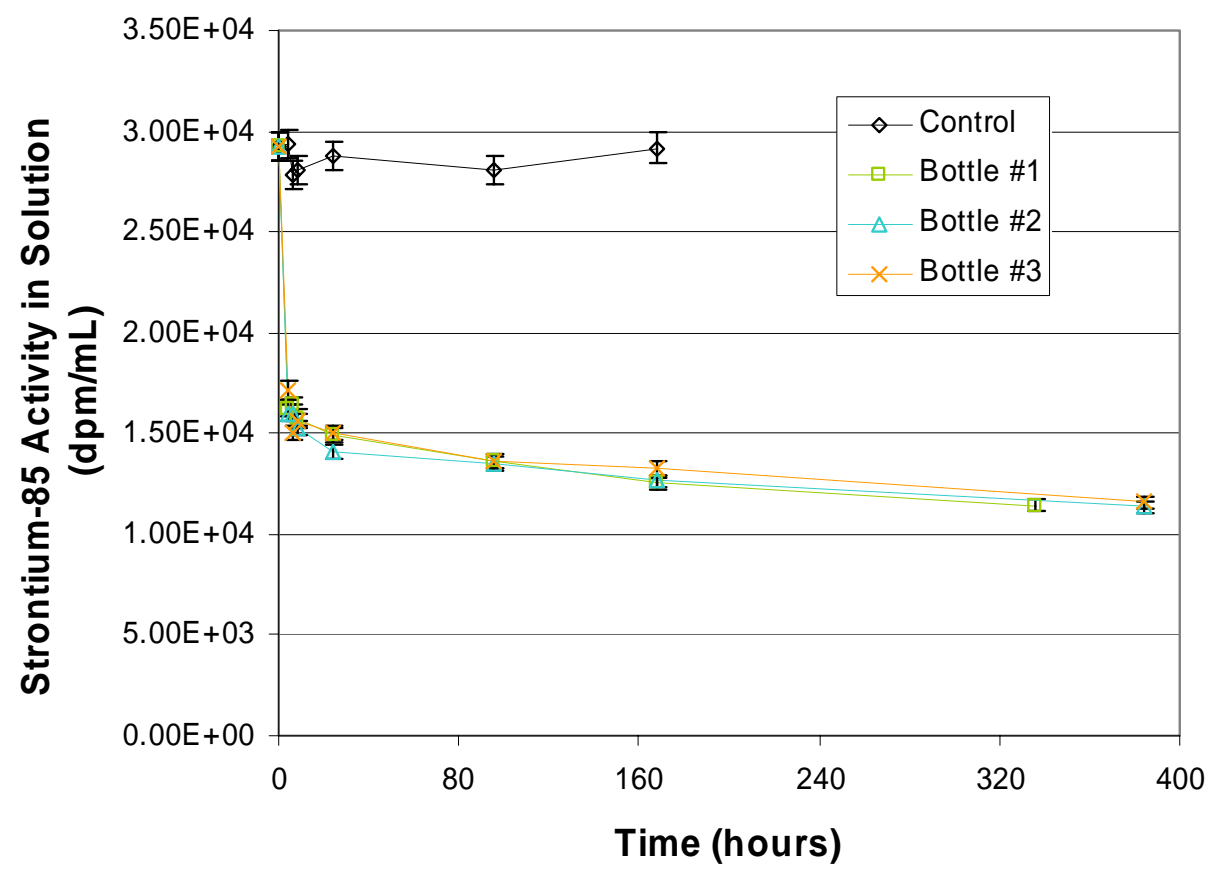

\subsubsection{Strontium Loading on MST}

Given the low strontium concentration in the simulant, we did not determine the loading of strontium onto the MST solids. We did measure the ${ }^{85} \mathrm{Sr}$ content in the recovered solids so that we could determine the ${ }^{85} \mathrm{Sr}$ mass balance.

\subsubsection{Strontium Activity Balance}

We used the same methodology described for plutonium to check the ${ }^{85} \mathrm{Sr}$ activity balance. Table 17 provides the calculated values and mass balances for each test. The average mass balance across all replicates and analyses is $92.8 \pm 2.12 \%$, which indicates a very good mass balance for ${ }^{85} \mathrm{Sr}$.

\section{Table 17. ${ }^{85}$ Strontium Activity Balance}

\begin{tabular}{|l|c|c|c|c|}
\hline & $\begin{array}{c}{ }^{85} \text { Sr in Filtrate } \\
\text { Before MST } \\
(\mathrm{dpm})\end{array}$ & $\begin{array}{c}{ }^{85} \text { Sr in Filtrate } \\
\text { after MST } \\
(\mathrm{dpm})\end{array}$ & $\begin{array}{c}{ }^{85} \text { Sr on MST } \\
\text { Solids } \\
(\mathrm{dpm})\end{array}$ & $\begin{array}{c}\text { \% Activity } \\
\text { Balance } \\
(\%)\end{array}$ \\
\hline Bottle \#1 & $2.58 \mathrm{E}+08$ & $9.71 \mathrm{E}+07$ & $1.49 \mathrm{E}+08$ & 95.2 \\
\hline Bottle \#2 & $2.58 \mathrm{E}+08$ & $9.68 \mathrm{E}+07$ & $1.35 \mathrm{E}+08$ & 91.9 \\
\hline Bottle \#3 & $2.58 \mathrm{E}+08$ & $9.85 \mathrm{E}+07$ & $1.37 \mathrm{E}+08$ & 91.2 \\
\hline
\end{tabular}




\subsection{DISCUSSION OF RESULTS}

The operational strategy for the ARP facility is considerably different than that planned for the Salt Waste Processing Facility. Due to the small batch reactor size, multiple small batches must be conducted to accumulate sufficient MST solids for washing and transferring to the Defense Waste Processing Facility (DWPF) for disposal. Current plans include a total of seventeen (17) separate batch contacts. This has the effect of exposing the MST solids to multiple contacts with fresh waste solutions. Consequently the loading of strontium and fissile elements could be higher than that in the SWPF which will contact the MST with a single or possibly two batches of waste solution. Given the potential for higher fissile loadings, CBU requested that SRNL measure fissile loadings at conditions that would bound conditions.

Maximum fissile loading will occur at high phase ratios and with waste solutions that contain high concentrations of the fissile elements $(\mathrm{Pu}, \mathrm{U}$ and $\mathrm{Np})$ and low strontium concentration. The average phase ratio over the 17 -contact process cycle is planned at $2500 \mathrm{~mL} / \mathrm{g}$ MST $(0.4 \mathrm{~g} / \mathrm{L} \mathrm{MST})$. After the first contact of the process cycle, the phase ratio for decreases as the total MST concentration increases. Thus for the $17^{\text {th }}$ contact, the phase ratio decreases a value of about 150 assuming no losses of the MST solids.

To provide bounding fissile loadings we measured the loading at a phase ratio of 42,500 $\mathrm{mL} / \mathrm{g}$ MST $(0.0235 \mathrm{~g} / \mathrm{L} \mathrm{MST})$. This is the ratio calculated if a single strike of MST at 0.4 $\mathrm{g} / \mathrm{L}$ MST were carried through the entire 17-contact process cycle. In normal operations only $1 / 17^{\text {th }}$ of the total quantity of MST solids present at the conclusion of the process cycle would have contacted waste solution at this equivalent phase ratio.

We also chose to measure the loadings in contact with a simulated waste solution that contains very high concentrations of uranium, plutonium and neptunium. The selected concentrations represent the highest expected values for waste solutions that will be processed through the ARP facility. Thus, the measured fissile loadings reported in this document should provide conservative values for normal operations in the ARP facility.

At the conditions tested we measured fissile loadings from the recovered MST solids of $2.95 \pm 0.390 \mathrm{wt} \%$ for plutonium, $11.2 \pm 1.89 \mathrm{wt} \%$ for uranium, and $0.809 \pm 0.0318$ wt $\%$ for neptunium. Calculations indicate good mass balance agreement for all three actinides. The measured loadings for uranium and plutonium in this study are considerably higher than those previously reported in support of the In-Tank Precipitation Facility. The higher loadings are consistent with that expected given the much higher phase ratio and higher fissile concentrations in the simulated waste solution.

The researchers calculated the theoretical maximum loading ${ }^{12}$ from an analysis of the MST physical structure. By comparing this to the sum of the loaded fissile species $(\mathrm{Pu}$, $\mathrm{U}, \mathrm{Np}$ ), we find the percentage of theoretical capacity is $34.6 \%$. If we assume only the 
fringe region of the MST physical structure is involved with fissile loading, this value increases to $74.6 \%{ }^{13}$ This indicates a high degree of loading for the MST and confirms the conditions of our tests were challenging.

\subsection{CONCLUSIONS}

From this work we derive the following conclusions.

- Testing measured the following fissile loadings onto MST at ARP relevant conditions after 2 weeks of contact (average of solution and solids data),

$\mathrm{Pu}: 2.79 \pm 0.197 \mathrm{wt} \%$,

$\mathrm{U}: 14.0 \pm 1.04 \mathrm{wt} \%$, and

Np: $0.839 \pm 0.0178$ wt \%.

- Fissile concentrations in the simulated waste solution suggests that equilibrium conditions may not have been reached after the 2-week contact time. At longer contact times in which the test system would reach equilibrium, the fissile loadings may be slightly higher than those reported above. However, given the very high phase ratios and high initial fissile concentrations in the simulated waste solution, we conclude that the reported values represent conservative loading values under conditions relevant to the ARP facility. 


\section{APPENDIX I. Simulant Measurements}

The simulant was prepared in two, 24-liter batches. The separate batches were combined into a single 50L carboy and allowed to equilibrate for 2 weeks. Three samples were pulled for a total of 9 analyses over the 2 week equilibrium period, giving the results in the table below.

\begin{tabular}{|lccc|}
\hline \multicolumn{1}{|c}{ Species } & Target & Result & Uncertainty \\
\hline sodium (ICPES) & $5.6 \mathrm{M}$ & 5.13 & $10 \%$ \\
nitrate & $2.6 \mathrm{M}$ & 2.59 & $10 \%$ \\
nitrite & 0.134 & 0.133 & $10 \%$ \\
sulfate & $0.521 \mathrm{M}$ & 0.508 & $10 \%$ \\
free hydroxide & $1.33 \mathrm{M}$ & $1.32-1.35$ & $10 \%$ \\
plutonium & $1200 \mathrm{ug} / \mathrm{L}$ & $880-890$ & $20 \%$ \\
uranium & $25,000 \mathrm{ug} / \mathrm{L}$ & 26,500 & $20 \%$ \\
neptunium & $500 \mathrm{ug} / \mathrm{L}$ & 477 & $20 \%$ \\
strontium & $50,000 \mathrm{dpm} / \mathrm{mL}$ & 30,400 & $2 \%$ \\
\hline
\end{tabular}

Based upon the analyses, SRNL with customer concurrence declared the simulant to be ready for use as measured. 


\subsection{REFERENCES}

${ }^{1}$ D. T. Hobbs and S. D. Fleischman, "Fissile Solubility and Monosodium Titanate Loading Tests", WSRC-RP-92-1273, February 12, 1993.

2 D. T. Hobbs, “Uranium Loading onto MST”, SRT-LWP-2002-00105, October 1, 2002.

${ }^{3}$ D. T. Hobbs and D. D. Walker, "Plutonium and Uranium Adsorption on Monosodium Titanate", WSRC-RP-92-93, August 13, 1992.

${ }^{4}$ M. J. Barnes, T. B. Edwards, D. T. Hobbs, and K. M. Marshall, "Strontium and Actinide Removal Testing with Monosodium Titanate and Other Sorbents", WSRC-TR2001-00436, Rev. 0, October 29, 2001.

${ }^{5}$ Maximum Uranium/Plutonium Loading on MST, SP-TTR-2005-00002, January 12, 2005.

${ }^{6}$ D. T. Hobbs, T. B. Peters and S. D. Fink, "Task Technical and Quality Assurance Plan for MST Fissile Loading Studies”, SRNL-WPT-2005-00032, Rev. 0, April 21, 2005.

${ }^{7}$ D. T. Hobbs, M. S. Blume and H. L. Thacker, "Phase V Simulant Testing of Monosodium Titanate Absorption Kinetics”, WSRC-TR-2000-00142, Rev. 0, May 24, 2000 .

${ }^{8}$ D. T. Hobbs, M. S. Blume and H. L. Thacker, "Screening and Evaluation of Alternate Sorbents and Methods for Strontium and Actinide Removal from Alkaline Salt Solutions", WSRC-TR-2001-00072, Rev. 0, February, 2001.

${ }^{9}$ D. T. Hobbs, M. D. Nyman and A. Clearfield, "Tailoring Sorbents for SRS Strontium and Actinide Separations: Optimized Monosodium Titanate and Pharmacosiderite Phase I Final Report”, WSRC-TR-2004-00322, Rev. 0, July, 2004.

${ }^{10}$ T. B. Peters, D. T. Hobbs and S. D. Fink, "Simulant Validation and Documentation for Standard Spiked Salt Solutions for MST Testing”, SRNL-WPT-2005-00096, October 21, 2005.

${ }^{11}$ M. J. Barnes, F. F. Fondeur, D. T. Hobbs and S. D. Fink, "Monosodium Titanate Multi-Strike testing", WSRC-TR-2004-00145, Rev. 0, April 29, 2004.

12 D. T. Hobbs, “Theoretical Cation Exchange Capacity of MST”, WSRC-NB-200500048, page 83, August 8, 2005.

${ }^{13}$ D. T. Hobbs, "Calculation of Volume Fraction Occupied by Fringe Region of MST", WSRC-NB-2004-00102, page 45, October 8, 2005. 